Vol 41 (2016) No 184 147-168

\title{
The Turkish Higher Education System from the Kaleidoscope of Martin Trow
}

\section{Enes Gök ${ }^{1}$}

\begin{abstract}
The present study examines the Turkish higher education system using Martin Trow's ten-aspect transition model from elite to mass to universal access in higher education. Using a semi-structured interview form, 13 eminent people in the higher education sector, including executive board members of the Council of Higher Education, government officials, university administrators and faculty members, and representatives from major educationrelated non-governmental organizations, were interviewed. Qualitative data was analyzed through descriptive analysis. Findings revealed that the Turkish higher education system has been under the influence of politics and vulnerable to threats from the continuously changing political landscape due to its centralized, non-autonomous structure. Problems arising from the rapid increase in the number of higher education institutions and the expansion of the system are more visible today in every segment of the system, from attitudes toward access and the role of the universities attributed by public, issues with diversity and equity in access, and central student selection and placement mechanisms. Additionally, problems related to state control and the centralized structure of the system, failures in institutional governance, and the lack of institutional autonomy as well as problems related to curriculum, forms of instruction, and the lack of mechanisms for quality control and accountability in the institutions were also discussed. Recommendations for further research and policy were provided.
\end{abstract}

Keywords

Keywords
Martin Trow
Expansion
Growth
Access
Higher Education
Politics
Elite to Mass to Universal Access
Turkey
Article Info
Received: 18.12.2015
Accepted: 20.03 .2016
Online Published: 27.04 .2016

DOI: $10.15390 /$ EB.2016.3193

\section{Introduction}

“Since the Justice and Development Party (AK Parti) took over the governance in 2002, Turkey has been witnessing a series of dramatic transformations in social, political, cultural and economic contexts-although both sides that support and oppose these transformations are available in the political arena and general public"(Gök, 2013, p. 227). Considering that higher education institutions (HEIs) are defined as the engine of nations' economic development or seem to be mechanisms for such transformation and economic growth (De Meulemeester \& Rochat, 1995; Blackstone, 2001; Johnstone, 2004; Gyimah-Brempong, Paddison, \& Mitiku, 2006), the Turkish higher education system - with its tremendous transformation and expansion both qualitatively and quantitatively in the last fourteen

\footnotetext{
${ }^{1}$ Recep Tayyip Erdogan University, Faculty of Education, Department of Educational Sciences, Turkey, enesgok@gmail.com
} 
years - receives a great deal of attention from both political leaders and the general public. As Figure 1 illustrates, Turkish HEIs grew in number during this period. The number of public institutions (PIs) doubled (from 53 to 109) and the number of foundation institutions (FIs) tripled (from 23 to 84) (YÖK, 2015; foundation dates were collected through T.C. Resmi Gazete [Official Gazette], 2015). Parallel to this growth, higher education student enrollments increased dramatically and this resulted in the rapid expansion of higher education in Turkey, consistent with the continuing and accelerating trend of expansion around the world (Çetinsaya, 2014). The expansion in higher education worldwide can be traced back to the early years of the twentieth century as a result of both national and global factors (Schofer \& Meyer, 2005).

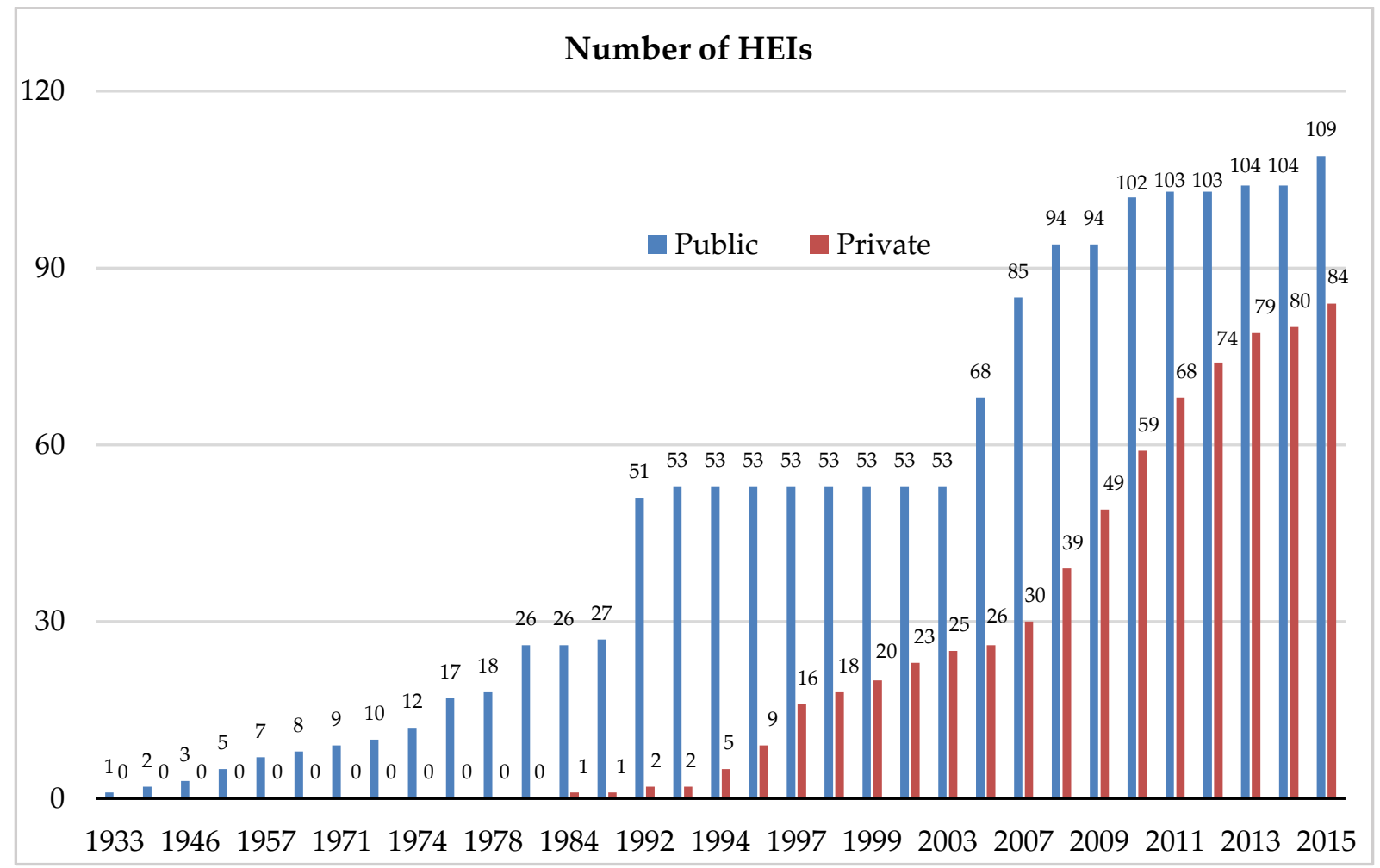

Figure 1. Number of Turkish universities, both public and private, between 1923-present.

Martin Trow (1973) discusses issues related to higher education expansion and proposes a model that categorizes higher education expansion-related transformation into three stages: (a) "elite higher education" that provides access to only $15 \%$ of the age grade; access to higher education is seen as a privilege for a small group of society; (b) "mass higher education" that serves between $15 \%$ to $50 \%$ of the age grade; access to higher education is seen as a right for students with formal qualifications; and (c) "universal access" that provides access to over 50\% of the age grade; higher education attendance is seen as an obligation. Statistics in Figure 2, drawn from four different sources (World Bank, 2013; World Bank, 2015; UNESCO, 2015; Günay, 2015), regarding gross enrollment rates of tertiary education in Turkey indicate that, from Trow's perspective, Turkish higher education before 1993 can be classified as an elite system, where access to higher education is limited to only a privileged group of the age grade. Although male students reached 15\% in 1989, the transformation was not complete until female students passed that transformation line. However, female students did not pass the transformation line until 1995 due to the gender gap in Turkish higher education - a gap still observable today. 
There is no statistical data available on Turkish gross enrollment rates before 1971, and student gross enrollment rates do not show a stable pattern between 1971 and 1993, as rates were increasing and decreasing throughout the years. Since 1993, there has been an upward trend in both male and female student gross enrollment rates. While the gross enrollment rates for the total Turkish higher education system reached the trend bar of $50 \%$ that represents the shift from the mass to the universal access stage in 2009, this transformation was completed only after 2010 for both women and men. It can be argued that the Turkish higher education system has been witnessing the universal access stage since 2010 . Theoretically, that was the time when attendance in higher education began to be seen as an obligation by the general public.

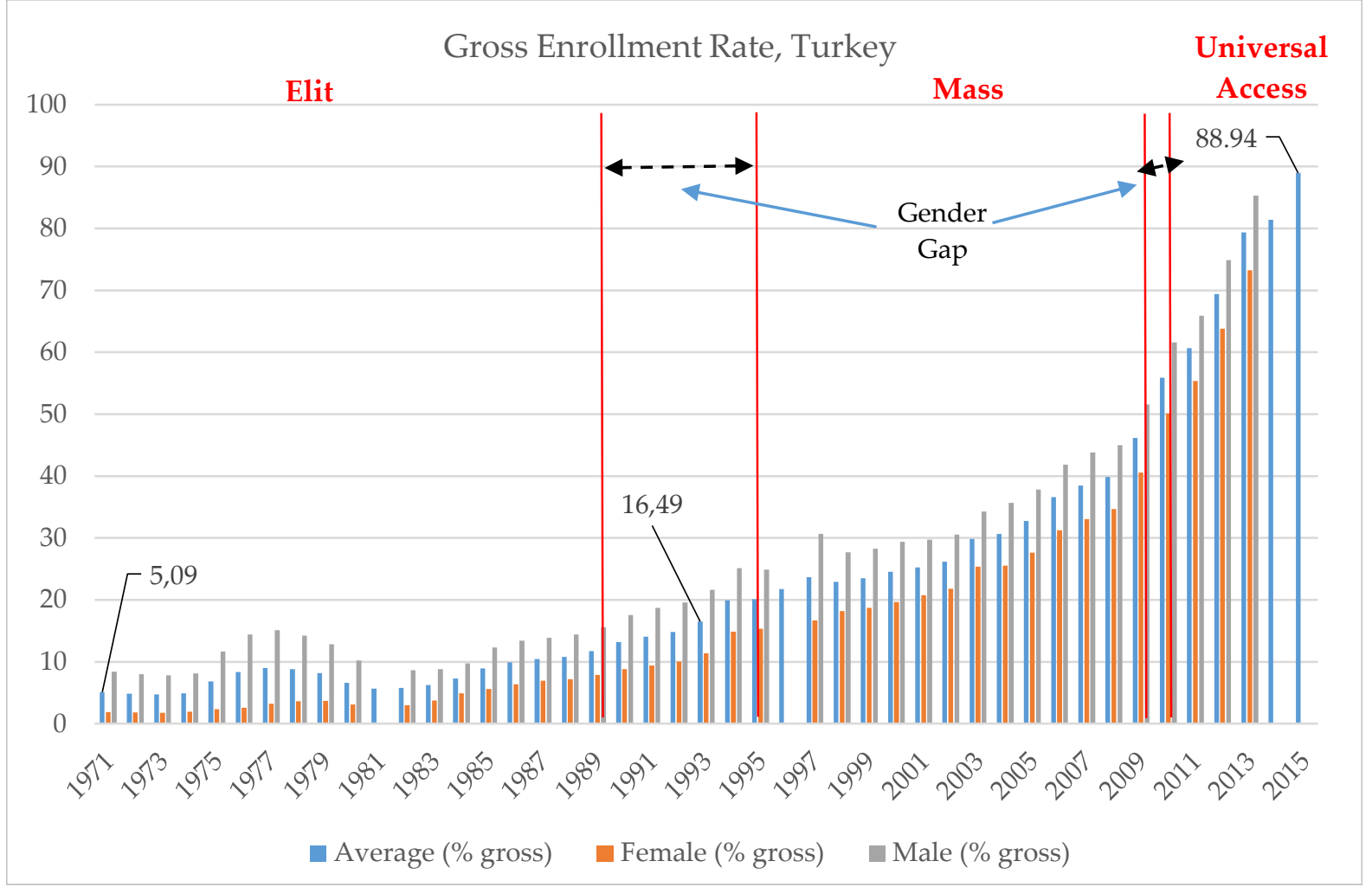

Figure 2. Tertiary gross enrollment rates, 1971-2015

Thus, this article aims to examine the Turkish higher education system's transformation by posing the research question: What social, political, and economic factors impact the expansion of the Turkish higher education system and how do key stakeholders, including senior academic staff, government officials, and representatives from major non-governmental organizations, see this transformation as well as its consequences based on Trow's (2007) ten-aspect conceptual model?

\section{Trow's Ten-aspect Model}

Trow (1973), in his discussion of higher education systems and institutions' transitions from elite to mass to universal access, argues that "the differences between these phases are quite fundamental and go through every aspect of higher education" (p. 6). He lists the ten aspects of higher education that are highly affected by the shift between elite to mass and mass to universal access. These aspects are i) attitudes toward access, ii) functions of higher education, iii) the curriculum and forms of instruction, iv) the student "career", v) institutional characteristics, vi) locus of power and decisionmaking, vii) academic standards, viii) access and selection, ix) forms of academic administration, and $\mathrm{x}$ ) internal governance (see Appendix A for Trow's conceptions of elite, mass and universal higher education summary table by J. Brennan, 2004). One caveat from Trow (1973) is that "the description of any phase cannot be taken as a full or adequate description of any single national system" (p. 18) since countries and systems of higher education vary as well as their institutions. 


\section{Expansion and Access in Higher Education}

"Expansion" is a slippery term and mostly associated with numerical values and quantifiable increases in student enrollments, budgets, and numbers of faculty members and institutions, but it is also crucial to consider unquantifiable developments, namely the diversification of students, cultures, and values as well as sophistication and development of ability in teaching, service, and knowledge production. In terms of the increases in student enrollments, the world has witnessed a tremendous expansion in the field of higher education in the twentieth century (Schofer \& Meyer, 2005). The gross enrollment rate (GER) in the world rose from $1 \%(500,000)$ in 1900 to around $20 \%$ (100 million) in 2000, an almost twentyfold increase in a century (Schofer \& Meyer, 2005). Over the next 13 years, there was a rapid increase in enrollment; by 2013, around 200 million students were enrolled, and the world's GER was 33\% (UNESCO, 2015). However, this growth was not homogeneous. According to UNESCO statistics, there is a significant gap among poor and wealthy countries; while the GER average for developed countries rose from $26 \%$ to $74 \%$ between 1970 and 2013, the GER average for developing countries increased from around $3 \%$ to $26 \%$. In other words, developing countries fell 43 years behind the developed countries in terms of access.

Schofer and Meyer (2005) investigate the rapid expansion of enrollments in higher education worldwide in the twentieth century using panel data. Their initial hypothesis was to examine the impact of global and national trends on the expansion of higher education worldwide as well as on national levels. While they hypothesize "economic development," "ethnic group competition," and "decentralization" to be the national-level factors against the expansion of higher education, "democratization," "development planning," "human rights," "scientization," and "world polity structuration" are trends of world polity in the global context impacting expansion. They find that "enrollments increase much more rapidly in the period after about 1960, and leap up in every type of country" as a result of "the rise of the new model society" associated with the trends linked to world polity mentioned above (Schofer \& Meyer, 2005, p. 916). This also resulted in the perspective shift in the new society from seeing "education for all" as a threat to society with the consequence of over-education and increasing unemployment rates to a perspective in which education is seen as a mechanism for human capital development. Other findings indicate that the speed of enrollments is slower in countries with diverse (ethnically and linguistically) populations and countries with centralized education structures as a result of government policy. In parallel with the argument posed by Schofer and Meyer (2005) that sees economic development as the trigger for the expansion of higher education, Pretorius and Xue (2003) indicate that "economic, political and social factors, as well as developments in science and technology, interact with the development of higher education" (p. 91).

Aside from the factors (both global and national) impacting the exponential expansion in higher education, their inevitable consequences at institutional, system, national, and global levels are also crucial in leading the discussion about future directions of the systems of higher education. The rapid expansion of higher education worldwide has resulted in increasing student access to higher education. The argument that expansion occurred worldwide mostly after World War II (Schofer \& Meyer, 2005), was also valid in the United States of America in the following two decades after the war (Astin \& Oseguera, 2004). However, the expansion and increasing access raised a different question. In their investigation of the expansion of U.S. higher education, Astin and Oseguera take the discussion to a different stage, elaborating on the idea of equity in access. They argue that while HEIs (circa 2004) are much more accessible in terms of quantifiable measures than 40 years prior, the question is if access to higher education increased in every form of post-secondary education. Specifically: "(a) How has access to the best institutions changed during the last two decades? (b) What are the possible reasons for any observed changes?" (Astin \& Oseguera, 2004, p. 322). They find that while federal- and state-level efforts such as affirmative action, financial aid, and outreach programs increased, they failed to close the widening gap and reduce the inequality in access to elite and prestigious colleges and universities due to increasing competition for access to such institutions. Additionally, the role of public HEIs in promoting equality and access for needy and disadvantaged students in U.S. higher education began to decline for the last two decades, as a result of increasing tuition paralleled with increasing costs, 
changing financial aid policies, and declining affirmative action applications; thus, "public higher education is rapidly becoming a barrier to equal opportunity in America rather than its promoter" (Mumper, 2003, p. 115). This is one consequence that emerged as a result of massification and expansion in higher education.

Martin Trow (2007), the founder of the transformation model on which this study is based, lays out the challenges HEIs and systems in transition should expect to encounter, especially those that are part of a system in which a government plays a crucial role in making critical policies regarding expansion and size; for instance, European countries. One of the challenges of transition toward massification is related to the changing flow of who comes to campus. Secondary schools, which once served as the promoters of liberal education and cultural knowledge, are no longer effective in fulfilling this role due to massification, and more students come to HEIs without such education. Another caveat proposed by Trow is that during an elite-to-mass transition, internal government and decision-making customs - by which senior professors who hold a chair play a fundamental role in the functions and decision-making of an institution-are shaken by the junior staff and students who are eager to participate in the decision-making process. The student and faculty population also transforms from a homogeneous structure to a heterogeneous one, with students and faculty members from different backgrounds and interests, as a result of expansion; this pushes the system toward "internal governance."

Additionally, institutions and systems experiencing transition will also face a changing relationship with the larger society and its economic and political actors and institutions. When institutions, as a result of expansion and transition, require more money and public resources for their functions, the emphasis on "accountability" rises while autonomy is decreased and the systems of higher education become more open and sensitive to the economic, social, and political activities of the country. However, it is crucial to note here, as Trow (2007) suggested, that transitions from elite to mass to universal access are not linear and homogeneous, and moving from one phase to the next does not mean that settings, functions, and patterns do not completely transform or change. That is, systems, for instance, moving from elite to mass do not require all of the elite institutions to experience this transformation. Instead, in a mass system, elite institutions can survive. In the same way, an institution in transition can keep some functions, patterns, and traditions from the earlier phase.

In their study, Özoğlu, Gür, and Gümüş (2016) examined the expansion-related challenges in higher education, specifically focusing on the current expansion strategy-establishing at least one HEI in each province, held in Turkey after 2006. This strategy resulted in the establishment of 41 new public HEIs. They report some major challenges as a result of this expansion strategy-including faculty shortages, a lack of educated administrative staff, ineffective allocation of public funds, failure to fill some program quotas, increasing pressure and scrutiny from local agencies, and a lack of philanthropy - that newly established HEIs have been facing since their foundation. However, the lack of adequate empirical research and policies driven by empirical findings are one cause of these challenges and there is a need for additional research on the expansion of Turkish higher education to contribute to policy development.

As the literature suggests, "explanatory research on the rapid expansion of higher education is less extensive than might be expected" (Schofer \& Meyer, 2005, p. 898); there is a need for more empirical research on the Turkish higher education system regarding expansion and growth (Özoğlu et al., 2016, p.3). This study aims to contribute to the literature on higher education expansion, specifically focusing on the Turkish case. 


\section{Method}

Qualitative research is related to the social construction of reality (Denzin \& Lincoln, 2005). To answer the research question posed, I examined the views of key stakeholders on the past, present, and future of the Turkish higher education system through the use of a semi-structured interview designed using Brennan's (2004) summary table and based on Trow's ten-aspect transition model; each question covers each aspect. Three experts (faculty members) examined a draft of the interview instrument and the finalized form was also piloted with a vice-rector for duration, clarity, and fit for purpose. Through piloting, researchers "will learn whether their research structure is appropriate for the study they envision... The pilot can alert them to elements of their own interview techniques that support the objectives of the study and to those that detract from those objectives"' (Seidman, 2006, p. 39).

A group of key policy people and scholars of higher education, based on their expertise and knowledge in the field, were identified. In total, 18 people were invited to participate in the study. However, one rector did not give any response to participation requests, one vice-rector of an HEI refused to participate due to his busy schedule, one professor-emeritus refused to participate because of his health conditions, one professor could not participate due to his conflicting schedule with the researcher, and one rector decided to participate but on the day of the interview decided to respond in written form to the interview questions, then later convey his responsibility to his consultant; as a result this rector was excluded from the study. At the end, 13 senior officials, representatives, and academicians participated in the study (See Table 1).

Table 1. Study Participants

\begin{tabular}{lllll}
\hline P\# & Position & $\begin{array}{l}\text { Interview } \\
\text { Date }\end{array}$ & Gender & $\begin{array}{l}\text { Interview } \\
\text { Type }\end{array}$ \\
\hline P1 & Faculty Member & 07.09 .2015 & Male & Skype \\
P2 & Rector Consultant/Senior Professor & 09.09 .2015 & Male & Face to Face \\
P3 & Dean & 14.09 .2015 & Male & Face to Face \\
P4 & Dean & 15.09 .2015 & Male & Face to Face \\
P5 & Director of an NGO & 17.09 .2015 & Male & Face to Face \\
P6 & Assistant Secretary - Ministry of National Education & 16.09 .2015 & Male & Face to Face \\
P7 & Rector & 29.09 .2015 & Male & Email \\
P8 & Executive Board Member - YÖK (CHE) & 01.10 .2015 & Male & Face to Face \\
P9 & Executive Board Member - YÖK (CHE) & 01.10 .2015 & Male & Face to Face \\
P10 & Executive Board Member - YÖK (CHE) & 03.11 .2015 & Male & Face to Face \\
P11 & Faculty Member & 04.11 .2015 & Female & Skype \\
P12 & Former Rector/Chairman of an NGO & 11.11 .2015 & Male & Face to Face \\
P13 & Faculty Member & 13.11 .2015 & Male & Face to Face \\
\hline
\end{tabular}

While 10 interviews were conducted face to face, one rector responded through email correspondence and two professors were interviewed via Skype due to conflicting schedules or unchangeable travel arrangements. During the interviews, study participants had a chance to elaborate on their ideas and opinions, since the instrument was semi-structured in nature. Participants also received a copy of the interview questions in advance so they had enough time to think about each question and refresh their perspectives. The researcher took notes and recorded the conversations (with participants' permission in advance) to be able to transcribe them as a whole. Conversation durations ranged from 24 to 82 minutes. The interviews were conducted in Turkish and translated into English by the researcher. Translations were also controlled by three faculty members. Participants were coded from P1 to P13 based on the dates of the interviews; P1 connotes the first participant interviewed and P13 connotes the last participant. The data was analyzed through descriptive analysis. 
Empirical findings are presented in the Results section. While some responses are given in quotation marks or as block quotations, others are nested in the findings as summaries; the actual meaning remains untouched. Thus, the research has been finalized within the Discussion and Conclusion sections with some research and policy recommendations.

\section{Results}

The findings were categorized based on the ten aspects of Trow's model. Themes emerging from these aspects were grouped under the following main sections based on the participant responses: Factors Impacting Higher Education; Access and Expansion; Administration and Governance; and Curriculum, Forms of Instruction, and Academic Standards.

\section{Factors Impacting Higher Education}

Participant perspectives regarding social, political, and economic factors impacting the system of higher education in Turkey revealed two major themes. One participant indicated that there are two sides of the coin impacting the higher education system:

First, the structures, purposes, and functions of HEIs have always been shaped by political events. Instances are the periods of 30s, 40s, 50s, the military coup in 1960, in 1980, and "February 28" [28 Şubat]. Second, global trends, especially after 1980s with globalization and neo-liberal politics, impacted higher education systems (P13).

Participant 8 also made similar observations regarding political influences on higher education. In terms of national-level factors, there was almost a consensus among study participants that, in the history of Turkish higher education, political developments and events have always influenced and impacted the system of higher education. However, in their examples, they differed in how they see the influence of political events.

Some participants (P2 and P5) indicated that during the political shift from the Ottoman State to the Turkish Republic, the Turkish higher education system was disconnected from its history, cutting its roots and connection with medresse schools. As one argued:

Unfortunately, we have rejected our history. As one foreign scholar states, we swept away everything with a vacuum cleaner. Nothing left. How could something like this happen (P2)?

Adding to this discussion, one of them argued that after the proclamation of the Turkish Republic, the system of higher education began to imitate Western systems, and there is nothing left to call "national" (p. 5). As one of the participants indicated, these political interventions are not particular to the republic period:

Higher education is a political initiative; from the Selçuklu States to today, ruling parties or government officials have always been interested in controlling higher education, and there is no exception in history (P4).

One participant discussed this intervention from a different point of view, arguing that political authorities, in their interventions, do not cooperate with HEIs. As he stated:

Politicians make decisions on higher education and put them into practice without listening to HEIs (P3).

Some of the participants considered political interventions from the establishment of new HEIs after 2006. As one argued, these institutions are related to the current ruling party as earlier institutions are related to the ruling parties of their periods:

When ruling parties change, ideologies also change, and they rule the country with these ideologies and can make radical changes to the systems. For instance, I am on a research project on the newly established HEIs, and participants identify themselves with the tendencies of the current ruling party, having conservative beliefs (P11). 
Somehow related to political interventions, the centralized structure of the system in Turkey was also criticized by some of the participants. For instance, one participant (P1) indicated that the Council of Higher Education (YÖK) and the law of higher education number 2547, as a result of the military coup, are used as a forcing mechanism on HEIs. Another participant argued that this central authority abolished the autonomy of the higher education system:

We, unfortunately, like centralization in Turkey. But this conflicts with the idea of higher education. In universal higher education, university autonomy is crucial, especially in institutional autonomy. I accept there is a misunderstanding of autonomy among some people. They think autonomy means expressing always an opinion on political issues or supporting a political party. However, what I say is that institutions should be able to develop their own missions and make their own budgets (P12).

Aside from factors related to politics and centralization, some other factors were also discussed. In terms of social and economic factors, one participant brought up underdevelopment. As he stated:

There was limited access and a limited number of HEIs as a result of the economic and social backwardness of the country. Another problem in this context was the gender gap in access to higher education. It has social and cultural roots in the history. For instance, there were tendencies among conservative families not to educate girls and women as a result of social backwardness; boys also had limited access in this context (P5).

Similar to Participant 13, two other participants also discussed the global factors impacting higher education. Specifically, while one participant indicated that "participation in the Bologna Process has Turkish higher education integrating some quality approaches into its system" (P7), another participant discussed the following global trends in higher education:

increasing demand and increasing access, changes in teaching methods, integrating information technology, growing diversity of higher education in terms of administration and function, shrinking direct public funding, increasing accountability and competition, internationalization, quality assurance, and rankings. These are not factors but trends impacting higher education (P10).

\section{Access and Expansion}

Participants revealed different opinions related to access in Turkish higher education and discussed the issue from a variety of standpoints. In their responses, there was almost a consensus that the increase in the number of HEIs in Turkey somewhat helped increase access to higher education, at least quantitatively. When they responded to the question of how society sees access to higher education, participants stated that, in the earlier years, access was seen by society as a privilege for a minority of the population, but later, with the help of the rapid expansion of higher education, it began to be viewed as an obligation. Some of the participants pointed to family efforts in the discussion. One participant articulated that "people in Turkey exert an extraordinary effort to have their children go to a university" (P8). Another one added: "and their efforts are admirable" (P4). However, some of the participants voiced concerns about society's attitude toward access. One participant was critical, saying that "people see university as a door that opens to jobs...it is not a place to provide jobs to everyone, but to provide skills they need or are interested in. However, society is not ready to embrace such consciousness yet" (P3). Another participant brought a different standpoint on public attitudes toward access, arguing that:

This question was meaningful in the past, but now it is out of date. In the past, access to higher education was a success...when the access problem was handled, it was thought that things would get easier, but now it is seen that graduates cannot find a job...unemployment rates of high school graduates is much lower than the unemployment rates of university graduates. In the past, access was seen as enough for 
success, but today, people are beginning to think about/learn what they will face after graduation even before they go to university (P10).

In talking about the access issues, some of the participants elaborated by explaining the motivations behind the public demand for access. Participants listed the motivations behind such increasing demand: seeing higher education as a job provider, status provider, or the ladder for mobility among social classes; neighborhood or family pressure; compulsory schooling; and a global trend toward "education for all." Specifically, two of the participants indicated that as a society we need to ask this question: "Should everybody have higher education?" As one of them indicated, during her education abroad she was discussing this issue with her colleagues, and it was a hot topic, especially in developed countries. She stressed the need for such questioning in Turkey by exemplifying her argument, stating that "...we need painters [house] and plumbers, [no doubt]" (P11).

Giving the same example, another participant stated that "we need plumbers, but we do not despise them. However, when you make them graduate from higher education, and give them a technician job, real problems start at that point. Their expectations are high but their ability to fulfill the job requirements are low. So there is no return from that point" (P6).

Another participant proposed a solution that the education system in Turkey, instead of imitating the West, needed to be restructured in such a way that people with low skills and no qualifications would leave the system at the required level of education for the jobs they could handle, without pushing them toward higher education (p.2).

Some of the participants discussed the access issue from the quality perspective, specifically emphasizing the issues related to the new HEIs established after 2000. One participant indicated:

Before 2008, access was limited in Turkey, but later Turkey witnessed fast development [rapid increase in the number of HEIs]. The historians of the future centuries will commemorate the 2000s as the years of the magnificent jumps (P8).

On the other hand, one participant suggested:

There should be higher education zones around the country. For instance, provinces with populations of 1-1,5 million should be considered as criterion. They established a lot of HEIs, the quality was compromised, and they became chef "high schools." Population criterion should be considered. Universities are considered as a source for money, for instance foundations institutions. 40-50 HEIs in those zones are enough (P2).

Almost proposing the same solution of establishing higher education zones instead of establishing an institution in each province, one participant argued:

Massification happened like this: The children of the elite class in the society still go to the respectable HEIs; others go to ordinary institutions (P4).

Another participant added:

I do not see access to higher education the same as access to newly established HEIs. I do have to say that I do not accept all of the HEIs as universities. Many of the HEIs in Turkey [not only newly established HEIs] are high private tutoring schools [yüksek dershane]. For me, university is a lifestyle; it has to contribute to your qualifications... it is not just taking a course and sitting in the cafeteria (P11).

She concluded her access discussion by arguing that, from this standpoint, access to "university" is still a privilege to small elite group of the society. 
The access discussions summarized above give some clues about what role/mission society ascribes to higher education. When participants were asked about the mission of HEIs, they revealed several different standpoints. From their responses, a couple of missions emerged. Most of the highlighted missions attributed to higher education involve the production of human resources that the country needs. One participant explained this mission with its historical and cultural background:

Certainly, there are a variety of purposes for universities: Education, research, and public service. However, in Turkey, the main purpose of higher education is to provide people a diploma and then find a job (P1).

Others also mentioned the mission of "educating the whole person." In addition to this, "searching for reality/truth" was also considered by some of the participants as the core mission of higher education. While one participant indicated that "value creation" was the main point and educating people, knowledge production, and public service are integrated and not separated submissions, two of the participants (P5, P4) argued that in Turkey there is no specific mission for the HEIs.

Questioning the access issue in Turkish higher education, some participants stated that even though the expansion decreased the pressure on access, it is still an issue officials need to handle, since half of the students who take the national entrance exam are left out of university education. Two of the participants (P3, P6) argued that pressure on the higher education system can only be handled by the restructuring of vocational high schools and two-year colleges in such a way that they can effectively work on training the human resources the country needs; in turn, this would decrease the demand for access and pressure on the gates of the HEIs.

It is important to consider that students are recruited to HEIs (both public and foundationnot-for-profit) through a national-level mechanism in which students' high school GPAs and scores from national-level examinations are used for selection and placement. In this regard, the majority of the participants indicated that in a system where the demand cannot be fully supplied, such mechanisms are necessary. Some participants favored the national entrance examination conducted by OSYM (the Measurement, Selection, and Placement Center); one indicated: "The Turkish entrance system is a completely egalitarian system, and OSYM is an exceptional institution in the world" (P8). On the other side, some participants criticized the danger in a system where selection and placement depend only on an exam. As one stated: "[OSYM] is an experienced institution in measurement and evaluation, but there should be a holistic model in which multiple components are integrated, such as the national-level exam, high school GPAs, teacher references, and oral examinations of the students" (P4).

Diversity was another point emphasized by participants as part of equity in access. Discussions of the participants varied on the equity problem. While religion, language, ethnic background, and internationalization were the topics elaborated on in their responses, most of the participants mentioned the equity question in terms of socio-economic status (SES). Some argued that, with this egalitarian system, there is no inequity in access to higher education. Additionally, Participant 1 indicated that higher education is getting more heterogeneous every day with the changing student and faculty populations on Turkish campuses. Others proposed some different arguments. Specifically, one participant mentioned that:

[In terms of SES], there is one type of higher education suitable for each level of SES (P5).

While criticizing the national education system as a mechanism fostering inequality, one participant argued that "education starts at the age of zero, and inequality starts at that age. [Having all of the students take the same exam], you do not sustain equality. On the one side, students with private tutoring and special courses; on the other side students from poor families with five or six children without such opportunities - they [confront the same exams]. Rich students are one step ahead of others, even before the competition starts" (P11). 


\section{Administration and Governance}

In this section, participant perspectives are detailed on a) who holds the power and who impacts institutional decision-making, and to what extent internal stakeholders share that role in terms of governance in higher education, b) the rectors' elections mechanism, and c) the education and experience of managers and administrators at different levels of the universities.

In responding to the question of power, voice in decision-making, and institutional operations, the participants revealed varied opinions. Although the question specified the internal and external stakeholders (politicians, senior professors, university foundations, interest groups from the public, employers, graduates, taxpayers, or the public in general), participant responses gathered around three main groups: politicians and the government, YÖK, and rectors.

The majority of the participants pointed out that some politicians, especially the ones in the government, have the most power and influence on higher education-related decision-making. However, the participants who shared this perspective conflicted in terms of their attitudes toward the interference of politicians and government in higher education. One of the participants standing against political influence articulated that:

The people and their ideologies that control YÖK [have power and influence on higher education]. YÖK is fully controlled by the government, and the government, its activities, and its plans are under the influence of a mostly America-driven global order and integration (P13).

On the other hand, one participant favored political influence, stating that:

The direct decision-maker is the government. This is expected. After all, politicians have first-hand knowledge of the needs of the country. Besides this, all foundations and nonprofit institutions are in the same situation. While some of the non-profit universities in Turkey were established by corporations and rich families and some others were founded by foundations interested in education, these families, corporations, and foundations have their influence as the government has (P5).

Aside from the government's role, some participants pointed at the Council of Higher Education. In talking about its influence on HEIs' decision-making, one participant first explained how YÖK was structured [the appointment of members and the chair] in detail and proposed the motivations and logic behind his support toward such influence:

There is no direct influence of the general public on universities and the higher education system, but through YÖK they influence it indirectly. The president of the republic is elected directly by the public. The council's (YÖK) members and chair are appointed directly by the president, so its legitimacy [and YÖK's influence] cannot be questioned even by the advanced democracies of the world (P8).

While one participant stated that "we have to see the difference here; public universities are strongly tied to YÖK, while foundation institutions have a moderate connection" (P11), another participant argued that:

Power is shared by YÖK and rectors. Society and taxpayers have no structural authorization in the system, given that the council was structured as a tutelage system by the pro-coup mindset (P1). 
Rectors' election is another discussion where participants shared their views on power in higher education. One participant noted that:

Rectors are appointed in many places around the world. Rectors' election is criticized in our system, but it was based on appointment in Turkey in the past. Today we have a half-election, half-appointment structure. In the U.S., governors appoint them. In our foundation institutions, the board of trustees appoints rectors and YÖK approves it. Nothing is anti-democratic in this system [elections in public institutions]. Both elections are criticized and appointments are criticized. But some changes can be made (P8).

On the other hand, a majority of the participants criticized rector elections with the following critiques: a) A person can be a perfect academician, but s/he can also be the worst administrator (P9), b) Direct appointments by the political authority should be carried out; no need to keep the university busy with procedures, no need for polarizations within the campus, and no need for blacklisting academicians (P5), and c) Academicians first go to politicians before they announce their candidacy (P3).

In addition to this, Participant 4 criticized the education and background of current rectors in particular as a result of the election system:

People should not be rectors without any experience in administration. Many of the rectors hesitate to take risks, hesitate to make changes in their institutions. Because [for example, an] obstetrician doctor becomes a rector, and he/she is afraid of doing something wrong.

Participant 9 added a point: “Rectors are elected, while deans are appointed by YÖK and not by rectors, so there is a balance here in terms of authorization and responsibility."

Talking about expertise and experience in the academic and executive positions in higher education, many of the participants pointed at the risks related to the amateur faculty members who hold executive positions, including rector itself. Participants first laid out the big picture in Turkish universities: a) heads of departments are amateur officers and they get experience after years of working; rectors, deans, and secretaries general are all academicians at HEIs (P1), b) "unfortunately, we are talking about competency here. Managerial positions in higher education do not receive the attention they deserve. It should be done very professionally. Academicians should not hold these positions" (P10). One participant asked: "Can/should every professor, just coming from practice in higher education, manage a university without the knowledge, theory, or background in higher education management as a professional field? (P11)"

Adding to this discussion, one participant argued that:

This is the problem experienced by the ministry of national education (MONE: MEB). In the 1920s and 1930s, there was this legislation principle; in the profession, teaching is essential [Meslekte öğretmenlik esastır]. This is experienced by the universities in the same way. This is the idea that a good professor can be a dean, can be a rector, or a good academician can be an administrator or inspector in the existing institutions. Yet, this means the denial of the science of administration as a separate discipline or expertise field. [Surprisingly], this principle is valid in administration but not in higher education. Such a discrepancy exists. To be an educator in higher education, there is no need for pedagogic formation; people can directly be a faculty member after their graduation from a doctoral degree. In this regard, faculty members should be provided with education formation and administrators and managers should get the administrative formation. And the administration of higher education should be divided in two: academic administration and managerial administration (P13). 
The majority of the participants revealed similar suggestions and stated that instead of amateurs, professionals should be hired in managerial positions, and instead of one rector at the university or dean at the faculty, administrative positions should be divided in two, similar to practices in the United States of America where the president, as a chief executive officer, is responsible for the budget, construction, strategic planning, and so on, while the provost, as a chief academic officer, is responsible for academic administration.

\section{Curriculum, Forms of Instruction, and Academic Standards}

Participants' perspectives gathering around forms of instruction, curriculum, academic standards, and quality are reported under this section.

Responses on curriculum revealed different standpoints. Participants mostly agreed that the former system had a strict curriculum by which universities were controlled in the past, but today there is some flexibility, such that HEIs began to take responsibility for deciding courses and faculty members decide on course content. Participants 8 and 9 both indicated that YÖK has been criticized for imposing a strict curriculum on universities, but YÖK's only two responsibilities in this regard are to decide on opening new faculties, departments, and programs and decide on human resources; both are at the request of universities. Additionally, Participant 9 detailed:

In faculties of education, there is this $75 \%$ core curriculum implemented, and faculties are $25 \%$ flexible in their choice... and this is especially useful for student mobility.

Adding to this discussion, Participant 7 indicated that in terms of curriculum, our universities are catching up with global trends and changes, especially the programs taught in English and whose textbooks are the same as the Anglo-Saxon institutions. However, for courses taught in Turkish, there is a textbook problem. Similar critiques were raised by another participant:

We are not in a good position with curriculum and academic programs. Universities choose courses based on their human resources [faculty members], but it should be based on students. Universities should not copy one another. For instance, in the departments of international affairs, universities in the south should integrate courses related to the Middle East, while Northeastern universities teach on Caucasus and Northwestern universities teach on the Balkan States (P5).

Another participant stated that:

We are the inactive actors of a centralized curriculum. YÖK decides on what courses we teach; academic autonomy is an illusion. In core classes, especially in public institutions, why should every institution teach the same topic and in a similar way? This is the illness of standardization (P11).

Talking about forms of instruction, most participants talked about current trends in forms of instruction in Turkish higher education and suggested that instruction in Turkey is still teacher-centered and, with some exceptions, technology integration in course instruction is limited.

Participants also talked about academic standards, quality in higher education, and the current mechanisms of quality assurance. Participants reported that although there are some initiatives to sustain quality, there are no national- or institutional-level standards and quality assurance mechanisms. As one participant posed:

In terms of hiring academic staff, there are some regulations, and each institution has their specific requirements. However, in terms of quality assurance, there is no settled mechanism in the fields of recruitment, performance, and evaluation of both students and faculty members (P7). 
Some participants indicated that "we are behind the world in terms of standards and quality assurance" (P3), "existing mechanisms do not work" (P4), "there is no national-level standardization in Turkey except some ranking systems" (P5), "there is no college entrance policy based on employment capacity" (P6). One participant stated that:

YÖK, at some point, works as an accreditation unit; in deciding student quotas for national placements, YÖK considers the capacity of the institutions (laboratories, number of faculty members, etc.) and there were also some autonomous accreditation agencies established recently (P8).

Another stated that:

Accreditation is vital and needs to be sustained urgently. In Turkey, today, there is an entrance criterion for some fields. For instance, there is an entrance quota for medical schools. This is a standard for input but there are no output criterions (P10).

Adding to this discussion, one argued that:

YÖK was founded to control around 26 universities in the 1980s. The problem here is that while the system has expanded rapidly throughout the years, there is no change or expansion in YÖK. Additionally, expansion is not homogeneous; while student numbers increased, faculty members, buildings, and laboratories did not increase at an equal rate. However, YÖK has been treating HEIs in the same way and focuses on just establishing new institutions and increasing the number of students in the name of education for all. Then you talk about student-centered education, and it is not possible with a classroom of a hundred students. They focus on input, but nobody cares about the output of the system (P11).

Making a similar argument, Participant 12 criticized YÖK's integration in quota decisions in terms of institutional autonomy, arguing that "there are only two criteria for the autonomy of the institution. These are the ability to hire your own students and faculty members and these are not in the hands of HEIs in Turkey" (P12). Participant 13 brought a different perspective and stated that:

What they do in higher education today in the name of quality is the result of neo-liberal policies around the world. Bringing standardizations, defining quality numerically and performance as quantified - higher education is parallel with global trends, but they are dangerous for the future of the system. 


\section{Discussion and Conclusion}

The Turkish higher education system has been experiencing enormous change and development, especially with the latest radical expansion in the 2000s in terms of increasing the number of HEIs and students, parallel with the changes and developments in the global arena. In this context, this study investigated the factors impacting higher education and the perspectives of key academic stakeholders, government officials, and non-governmental organizations on Turkish higher education from the aspects developed by Martin Trow.

Participant perspectives on what has been impacting higher education systems revealed two major themes consistent with the findings of earlier studies (Torres \& Morrow, 2000; Vaira, 2004; Schofer \& Meyer, 2005; Boli \& Thomas, 1997) that global and national factors impact and shape the systems of higher education and their institutions. Although both factors were highlighted, participant discussions mostly focused on national-level factors; they spoke about the roles of politics and government intervention, central structure, and autonomy. Specifically, most of the participants highlighted the political factors that have been impacting the Turkish higher education system, indicating that milestones of the Turkish higher education system parallel with the milestones of political tensions in history, exemplifying the role that HEIs played during the Selcuk and Ottoman periods (Akyüz, 2013), the reforms and changes in the system of higher education after the proclamation of the Turkish republic in 1923, the military interventions in 1960 and 1980, and the structural change of 1946 when the parliament moved from a one-party to a multi-party system (Günay \& Günay, 2011). Medresse schools' major role in training government officials during the earlier periods (Akyüz, 2013) was also discussed by some of the participants.

This government/central power and higher education relationship was not particular to Islamic states in those periods. For instance, similar relationships between universities and the church were witnessed during the early forms of Western HEIs (Makdisi, 1970). The political influence during the Ottoman period was also witnessed during the shift from an Islamic state to a secular republic. In speaking about this shift and the influence of the state, some participants critiqued that there was a political intention to disconnect the system of higher education from its historical roots, consistent with Berkem and Aras' argument that "the closure of Darulfunun is somewhat linked to political concerns as much as scientific expectations" (Berkem \& Aras, 2010, p. 18). Further, participants also discussed the centralization of Turkish higher education after the foundation of YÖK and the declaration of Law 2547 as mechanisms for control and intervention in higher education that ruin institutional autonomy. The situation is also significant in earlier discussions of scholars (Mızıkacı, 2006; Çelik, 2011; Çelik \& Gür, 2014). Additionally, the development of Turkish higher education and the experience in massification contradict with arguments by Schofer and Meyer (2005) that there is a shift in national planning in which centralization gave way to decentralization through institutional-level planning close to the end of the twentieth century; in fact, there was a growing centralization in the Turkish system of higher education, especially at the end of the twentieth century. Findings also contradict with the findings of Schofer and Meyer (2005) that, due to governments' capacity to control/limit enrollments, expansion is slowed in mostly centralized higher education systems; this is the opposite in the Turkish case with the latest rapid expansion through the establishment of new public HEIs.

In countries where there are strong financial ties between the HEIs and governmental bodies and political control is high through central mechanisms, the increasing demand for accountability over public funding and quality is more visible. Several steps need to be taken by policymakers, stakeholders in the system, and the institutions of higher education. First, factors both national and global need to be fully examined in order to develop a long-term vision and system-wide planning for the future. Political influences on higher education should be balanced through research-oriented policies. This balance, as Çelik and Gür (2014) suggest, should be established through developing accountability mechanisms and increasing institutional autonomy. 
Talking about public attitudes toward higher education, participants indicated a shift in public attitudes toward higher education throughout the years, from seeing it as a privilege to seeing it as an obligation consistent with the model specification by Trow (1973). The main motivation behind seeing higher education as an obligation seems to be a result of the perspective that completing higher education is the only way to find a proper job with some level of social status. Despite these expectations, as one participant indicated, unemployment rates are higher in higher education compared to earlier levels of education. This is consistent with earlier studies (Pretorius \& Xue, 2003; Schofer \& Meyer, 2005; Bai, 2006) that found that unemployment is another problem facing graduates of HEIs, and sharp expansion worsens the situation. Additionally, due to academic inflation or what Collins (2002) calls "credential inflation," the Turkish higher education system produces more graduates against a limited number of jobs. Moreover, those available low-status jobs, considered by study participants to be necessary for society, are not considered by these graduates due to the jobs' lower social status.

Higher education's massification and expansion, as a result of the "education for all approach" encouraged by democratization and progress in human rights (Schofer \& Meyer, 2005), seems to have caused, on the one hand, academic inflation; on the other hand, it has caused a fear in society that students with university degrees are seen as overqualified graduates for those low-status positions. At this point, increasing pressure for access, as one interviewee indicated, gave way to increasing demands for jobs after graduation. Additionally, fallacious strategies, policies, and practices that have been implemented in Turkish structure worsen the situation. For instance, in order to decrease the pressure on higher education, there is an unplanned movement giving pedagogic formation to other faculties, allowing HEIs to offer teacher formation certificates to its students and graduates (regardless of the program); on the other side, periodic announcements are made by the Turkish ministry of national education and ministry of finance that the gap in teacher shortage is almost closed in the country. One policy recommendation provided by the participants was that vocational high schools and two-year vocational colleges should be renovated and strengthened in such a way that they will close the workforce gap from which Turkish industry suffers; this could also reduce the pressure resulting from the increasing unemployment rates of university graduates.

On access, collected data were mostly linked to the current rapid expansion through the establishment of new HEIs in Turkey. From the quality standpoint, participants criticized the expansion policy. While some participants saw the rapid increase in the number of HEIs as a courageous initiative for having equality in access, and some of them saw it as a source of increasing diversity so that today there is one type of HEI for each type of student, especially those of each socio-economic status, another participant saw the establishment of new HEIs as a balloon that creates an access illusion. This is consistent with Yavuz's (2010) arguments that the majority of public HEIs, including newly established ones, are higher secondary schools; additionally, this is not a quantitative problem but a quality problem. Access to those prestigious institutions is still limited. These discussions brought up the arguments by Teichler, Hartung, and Nuthmann (1980) that "not even the most modest efforts toward equality of opportunity - removal of institutional barriers in education to guarantee each social group an equal chance-seem destined to succeed" (p. 59); an argument by Pretorius and Xue (2003) is consistent with the findings of the present study:

An important aim for expanding higher education in many developed countries has been to improve equality, but the results have been far from satisfactory. Furthermore, while former inequalities may decline, new inequalities, such as the disproportion of social participation in prestigious institutions or fields, may emerge (p. 91).

For already-applied strategies and established institutions, enhancement and restoration policies need to be created under the light of and recommendations by earlier research (for instance, Özoğlu et al., 2015). Further studies also need to direct possible future policies. The discussions of the participants related to access, and their concerns regarding the current student selection and placement mechanism, should also be reconsidered. 
Discussing power and influence in higher education administration and decision-making, political influences in the history of higher education were brought to the table one more time by the study participants. With the expansion of the system in mind, Trow (1973) stresses that "growth raises the question of the relation of the state to higher education in new and disturbing ways" (p. 4). Concerns about the interaction between the state and the system of higher education become visible and voices and growls grow louder. In this context, participants specified three main players impacting decisionmaking: government and politicians, the Council of Higher Education as the central body, and rectors with one-person authority. Specifically, while some participants legitimized government and Council of Higher Education influence on the system as the indirect participation of society and taxpayers, others criticized these influences in terms of interference in institutional autonomy. Discussions of these influences brought about one major verity, as one participant summarized that the system of higher education in Turkey has been controlled by ideologies; the ideology that controls the government and the Council of Higher Education controls the system of higher education when those groups implement their own agenda; there is no exception to this in the history (for example, the headscarf ban and the alienation of preacher high schools [imam hatip liseleri] from higher education using controversial score calculations).

Institutional autonomy restrictions criticized by the participants highlighted an ongoing problem of the system of Turkish higher education throughout the history, consistent with the discussions of Barblan, Ergüder, and Gürüz (2008) regarding the violations of institutional autonomy in the history. On the other hand, in the context of financial autonomy highlighted in the literature (Mızıkacı, 2006; Barblan et al., 2008; Çelik, 2011; Çelik \& Gür, 2014) in which public HEIs are strongly tied with the state in terms of financial resources, the issue of institutional accountability needs to be discussed. The expectations of the government and state also need to be considered, since they are the main providers-or, in economic terms, main "sponsors (employees)"-of the system. Previous suggestions of scholars (Çelik \& Gür, 2014) should be considered, particularly that the mission and structure of the council should be radically converted so that it fulfills regulatory and coordination roles only, and the establishment of new agents to fulfill that goal should represent not only internal but also external stakeholders. There needs to be a political platform on which the expectations of the government and state are handled while the influences of ideologies on higher education are minimized along with securing institutional autonomy and the freedom of academic stakeholders in the institutions of Turkish higher education.

The concerns related to the role of the rector as the ultimate authority at the institution and the "administratively inexperienced" faculty members holding administrative positions also needs to be considered, as stated by the participants. Consistent with these arguments, earlier studies (Gök \& Gümüş, 2015; Özoğlu et al., 2016) discuss such applications and suggest that mechanisms such as inservice training for the current administrators or graduate-level education courses and degrees in the field of "higher education management" will further the professionalization of administrative staff at HEIs. Additionally, the separation of academic and administrative officers in the overall administration of HEIs needs to be considered by the policymakers. Further research on the feasibility of such mechanisms is needed. 
Under the management of YÖK, data from this research revealed that the curriculum in Turkish higher education was previously a source of academic control in HEIs, but current modifications brought some flexibility, which institutions and faculty members enjoy today, as related (to some extent) to their course selection and course content. Although some flexibility exists in action, the criticisms of participants mostly focused on the individual practices of faculty members in their courses. While one respondent criticized the quality and misbehavior of the faculty members, another mentioned limitations in the forms of instruction; the impossibility of shifting from teacher-centered to studentcentered teaching; and, due to the heterogeneous expansion of the system, faculty, infrastructure, and service shortages against increased student quotas (controlled by YÖK) in the programs of HEIs. These findings are also consistent with earlier studies (Özoğlu et al. 2016) and these conditions are more severe in the institutions established as part of the steep expansion. And, as some participants added, the lack of effective quality standards - assurance mechanisms that control the academic practices of HEIsmakes the system more vulnerable to the threats of the rapidly changing higher education landscape.

Implementation of the findings requires responsible bodies to consider that there are several limitations to the present study. While the study is significant in partially filling the literature on the empirical examination of Turkish higher education and the integration of different stakeholder groups (including senior officials from the government and YÖK, faculty members, representatives from education-related NGOs, and administrators from the university), it does not integrate all stakeholders in the examination. This study recommend that further research expand on this inquiry by integrating other crucial stakeholder groups, including students, families, taxpayers, employers, and representatives from society and local communities.

In conclusion, considering the discussions above and Trow's model specifications, the Turkish higher education system seems to incorporate the features of both elite and mass systems, which is also expected according to Trow (2007). In these cases, while elite institutions continue to operate under the control of the central body, mass institutions serve the expectations of the larger society. Although the numerical values (gross enrollment rates) suggest that the system should be classified under the universal access line, the Turkish system seems to be a couple of steps behind that line with its current problems. Analysis of the perspectives of key stakeholders in Turkish higher education demonstrates that the higher education system in Turkey has been vulnerable to political influences and turbulences throughout history; the present system is no exception. While there are other social and economic factors impacting higher education, political influences are key to understanding the current structures, operations, and policies of the system.

Additionally, as a result of rapid expansion, the problems have intensified and somehow mutated so that earlier visions and policies projected for today are failing to respond to the changing higher education landscape. An emerging conflict becoming more visible in the system is that, on the one side, student and faculty populations are rapidly increasing and diversifying, and varying HEIs with different missions and strategies have been established, resulting in the most heterogeneous level in its history, shaking the authority of the central body. On the other side, the Council of Higher Education, with the influence of politicians, treats the system as if it were 35 years ago and insists on keeping the system homogeneous with central government mechanisms - for instance, central student and faculty recruitment procedures-and a central curriculum. Further, notwithstanding the intention of keeping the system under the control of a central unit, there are not fully agreed-on, effective mechanisms to control and upgrade the quality of the teaching, learning, research, and service activities of the HEIs. 
The big picture of the system in Turkey is this: Stakeholders are mostly unsatisfied with the current politics-controlled central system and its practices. HEIs, as a result of unplanned rapid expansion, are in turmoil in terms of daily operations, from individual faculty members' teaching and research responsibilities to executive structures and the governance of an HEI. The system, having undergone such massification, is failing to respond to the needs of society and the country as a whole, and its institutions are suffering from unplanned policies and save-the-day strategies, resulting in unpredictability.

On the other hand, regardless of the lack of a clear vision and well-established future agenda, as one interviewee underlined, the Turkish higher education system, with the help of both national and global factors, is becoming part of a more global and extensively expanded higher education system. This was also emphasized by Schofer and Meyer (2005). One crucial recommendation is that the central structure and authority should be decentralized by replacing them with coordination mechanisms giving more flexibility to the HEIs. In any case, more empirical research is needed to understand the current problems and generate possible solutions for the problems relating to the Turkish context for sustaining the future.

\section{Acknowledgements}

This research was supported by the Scientific Research Projects Unit at Recep Tayyip Erdoğan University. Project ID: 2015.53001.105.02.02. 


\section{References}

Akyüz, Y. (2013). Türk Eğitim Tarihi M.Ö.1000-M.S.2013. Ankara: Pegem Akademi.

Astin, A. W., \& Oseguera, L. (2004). The declining "equity" of American higher education. The Review of Higher Education, 27(3), 321-341.

Bai, L. (2006). Graduate unemployment: Dilemmas and challenges in China's move to mass higher education. The China Quarterly, 185, 128-144.

Barblan, A., Ergüder, Ü., \& Gürüz, K. (2008). Higher education in Turkey: Institutional autonomy and responsibility in a modernising society. Bologna: Bologna University Press.

Berkem, A. R., \& Aras, N. K. (2010). Modern üniversite çağının Türkiye' de başlaması. In N.K. Aras, E. Dölen, \& O. Bahadır (Eds.), Türkiye'de Üniversite Anlayışının Gelişimi (1861-1961). Ankara: TÜBA Bilimler Akademisi.

Blackstone, T. (2001) Why learn? Higher education in a learning society. Higher Education Quarterly, $55(2), 175-84$.

Boli, J., \& Thomas, G. M. (1997). World culture in the world polity: A century of international nongovernmental organization. American Sociological Review, 62(2), 171-190.

Brennan, J. (2004). The social role of the contemporary university: Contradictions, boundaries, and change. In Ten years on: Changing higher education in a changing world (pp. 22-26). The Open University: Milton Keynes.

Collins, R. (2002). Credential inflation and the future of universities. In S. Brint (Ed.), The future of other city of intellect (pp. 23-47). Stanford, CA: Stanford University Press.

Çelik, S. (2011). Turkish higher education at the crossroads: Critical issues of systematic and institutional structures. Higher Education Review, 43(2), 18-41.

Çelik, Z., \& Gür, B. (2014). The governance of higher education systems and university autonomy: Global trends and the case of Turkey. Journal of Higher Education and Science, 4(1), 18-27. doi:10.5961/jhes.2014.085

Çetinsaya, G. (2014). Büyüme, Kalite ve Uluslararasılaşma: Türkiye Yükseköğretimi İçin Bir Yol Haritası. Retrieved from https://yolharitasi.yok.gov.tr/docs/YolHaritasi.pdf

De Meulemeester, J. C., \& Rochat, D. (1995). A causality analysis of the link between higher education and economic development. Economics of Education Review, 144(4), 351-361.

Denzin, N. K., \& Lincoln, Y. S. (2005). The sage handbook of qualitative research (3rd ed.). California: Sage Publications.

Gök, E. (2013). The future of higher education in Turkey: From an elite to a mass society. In The Proceedings of the $10^{\text {th }}$ International Workshop on Higher Education Reform (pp. 227-227). Ljubljana, Slovenia: Centre for Education Policy Studies. Retrieved from http://www2.cmepius.si/files/cmepius/userfiles/bolon_eksp/HER_proceedings_2013.pdf

Gök, E., \& Gümüş, S. (2015). Akademik bir alan olarak yükseköğretim yönetimi. In A. Aypay (Ed.), Türkiye'de Yükseköğretim: Alanı, Kapsamı ve Uygulamaları. Ankara: Pegema.

Günay, D., \& Günay, A. (2011). 1933'den günümüze Türk yükseköğretiminde niceliksel gelişmeler. Yükseköğretim ve Bilim Dergisi, 1(1), 1-22.

Günay, D. (2015, 14-16 October). Üniversiteye felsefi bir bakış ve Türk Üniversiteleri. Paper presented at the International Higher Education Studies Conference (IHEC), İstanbul, Turkey.

Gyimah-Brempong, K., Paddison, O., \& Mitiku, W. (2006). Higher education and economic growth in Africa. Journal of Development Studies, 42(3), 509-529. doi:10.1080/00220380600576490

Johnstone, D. B. (2004). The economics and politics of cost sharing in higher education: Comparative perspectives. Economics of Education Review, 23, 403-410. doi:10.1016/j.econedurev.2003.09.004

Makdisi, G. (1970) Madrasa and university in the middle ages. Studia Islamica, 31, 255-264. 
Mizıkacı, F. (2006). Higher Education in Turkey. UNESCO/CEPES, Monographs on Higher Education, Bucharest.

Mumper, M. (2003). The future of college access: The declining role of public higher education in promoting equal opportunity. The Annals of the American Academy of Political and Social Science, 585(1), 97-117.

Özoğlu, M., Gür, B. S., \& Gümüs, S. (2016). Rapid expansion of higher education in Turkey: The challenges of recently established public universities (2006-2013). Higher Education Policy, 29(1), 2139. doi:10.1057/hep.2015.7

Pretorius, S. G., \& Xue, Y. Q. (2003). The transition from elite to mass higher education: A Chinese perspective. Prospects, 33(1), 89-101.

Schofer, E., \& Meyer, J. W. (2005). The worldwide expansion of higher education in the twentieth century. American Sociological Review, 70, 898-920.

Seidman, I. (2006). Interviewing as qualitative research: A guide for researchers in education and the social sciences (3rd ed.). New York: Teachers College Press.

Teichler, U., Hartung, D., \& Nuthmann, R. (1980). Higher education and the needs of society. Windsor: NFER Publishing Company.

T. C. Resmi Gazete [Official Gazette]. (2015). Retrieved from http://www.resmigazete.gov.tr/

Torres C. A., \& Morrow, R. A. (2000). The state, globalization, and educational policy. In N. C. Burbules, \& C. A. Torres (Eds.), Globalization and Education Critical Perspectives. London: Routledge University Press.

Trow, M. (1973). Problems in the transition from elite to mass higher education. Berkeley, CA: Carnegie Commission on Higher Education.

Trow, M. (2007). Reflections on the transition from elite to mass to universal access: Forms and phases of higher education in modern societies since WWII. In J. J. F. Forest, \& P. G. Altbach (Eds.), International Handbook of Higher Education (pp. 243-280). Netherlands: Springer.

UNESCO. (2015). UNESCO Institute for Statistics. Retrieved from http://data.uis.unesco.org/

Vaira, M. (2004). Globalization and higher education organizational change: A framework for analysis. Higher Education, 48(4), 483-510.

Yavuz, A. (2010). Universities are becoming "high schools" and high schools are "disappearing"!. Çă̆daş Ĕ̆itim Dergisi, 35(374), 30-40.

YÖK. (2015). Yükseköğretim Kurulu: Üniversitelerimiz. Retrieved from http://www.yok.gov.tr/

World Bank. (2013). World Development Indicators. Retrieved from http://databank.worldbank.org/

World Bank. (2015). World Development Indicators. Retrieved from http://databank.worldbank.org/ 


\section{Appendix}

\begin{tabular}{lll} 
& Elite (0-15\%) & Mass (16-50\%) \\
\hline i) Attitudes to access & $\begin{array}{l}\text { A privilege of birth or } \\
\text { talent or both }\end{array}$ & $\begin{array}{l}\text { A right for those with } \\
\text { certain qualifications }\end{array}$ \\
\hline $\begin{array}{l}\text { ii) Functions of higher } \\
\text { education }\end{array}$ & $\begin{array}{l}\text { Shaping mind and } \\
\text { character of ruling class; } \\
\text { preparation for elite roles }\end{array}$ & $\begin{array}{l}\text { Transmission of skills; } \\
\text { preparation for broader } \\
\text { range of technical and } \\
\text { economic elite roles }\end{array}$ \\
\hline $\begin{array}{l}\text { iii) Curriculum and } \\
\text { forms of instruction }\end{array}$ & $\begin{array}{l}\text { Highly structured in terms } \\
\text { of academic or } \\
\text { professional conceptions } \\
\text { of knowledge }\end{array}$ & $\begin{array}{l}\text { Modular, flexible and } \\
\text { semi-structured sequence } \\
\text { of courses }\end{array}$ \\
\hline
\end{tabular}

Universal (over 50\%)

An obligation for the middle and upper classes

Adaptation of 'whole population' to rapid social and technological change

Boundaries and sequences break down; distinctions between learning and life breakdown

"sponsored" after

iv) The student 'career' secondary school; works uninterruptedly until gains degree
Increasing numbers delay entry; more drop out

Homogenious with high and common standards; small residential

v) Institutional characteristics communities; Clear and impermeable boundaries

Comprehensive with more diverse standards; 'Cities of intellect'--mixed residential/commuting; Boundaries fuzzy and permeable

\section{Ordinary political} processes of interest groups and party programmes

\section{Variable}

system/institution 'become Criterion shifts from holding companies for quite different kinds of academic enterprices'

$\begin{array}{ll}\text { Meritocratic plus } & \text { 'open', emphasis on } \\ \text { 'compensatory } & \text { 'equality of group } \\ \text { programmes' to achieve } & \begin{array}{l}\text { achievement' (class, } \\ \text { equality of opportunity }\end{array} \\ \text { ethnic) }\end{array}$

Former academics now full-time administrators plus large and growing bureaucracy 'standards' to 'value added'

Much postponement of entry, softening of boundaries between formal education and other aspects of life; termtime working

Great diversity with no common standards; Aggreagtes of people enrolled but rarely or never on campus; Boundaries weak or nonexistent

(The Daily Mail!) 'Mass publics' question special privileges and immunities of academe

More specialist full-time professionals. Managerial techniques imported from outside academe ix) Forms of academic administration are 'amateurs at administration', elected/appointed for limited periods
Professors and junior staff with increasing influence from students
Breakdown of consensus making institutional governance insoluble; decision-making flows into hands of political authority

Note: Trow's conceptions of elite, mass and universal higher education. Reprinted from "The social role of the contemporary university: Contradictions, boundaries, and change" by J. Brennan, 2004. In Ten years on: Changing higher education in a changing world (pp. 22-26). The Open University: Milton Keynes. Reprinted with permission. 